\title{
Management of Lecturers Resource Development at Higher Education
}

\author{
Isthifa Kemal ${ }^{1,2}$, Suryadi ${ }^{1} \&$ Unifah Rosyidi $^{1}$ \\ ${ }^{1}$ Education Management Doctoral Program, Universitas Negeri Jakarta, Indonesia \\ ${ }^{2}$ Awardee LPDP, Finance Ministry \\ Correspondence: Isthifa Kemal, Education Management Doctoral Program, Universitas Negeri Jakarta, Indonesia. \\ E-mail: Isthifakemal_mp16s3@mahasiswa.unj.ac.id, isthifakemal@gmail.com
}

Received: August 8, 2019

doi:10.5430/ijhe.v8n5p246
Accepted: August 30, 2019

Online Published: September 18, 2019

URL: https://doi.org/10.5430/ijhe.v8n5p246

\begin{abstract}
The purpose of this study was to determine the management of the development of lecturer resources in the tri dharma of higher education in STKIP Bina Bangsa Getsempena (STKIP BBG) Banda Aceh. This research is focused on the implementation of the tri dharma of higher education. This research uses a qualitative method with a case study approach. Data were collected by interview, observation and documentation study, then analyzed qualitatively. As for data analysis techniques, descriptive-inductive and reflective models are specifically used in this study. The results of these research programs in the implementation of the tri dharma of higher education are carried out on an ongoing basis so that lecturer resources are maintained. All of them in the management of lecturer resource development rests on the vision of the institution to make universities superior.
\end{abstract}

Keywords: development management, lecturer, tri dharma perguruan tinggi

\section{Introduction}

The low quality of Indonesian human resources can be seen from the low quality of education in Indonesia. This can be observed from the report of the United Nations (UN) for education, the United Nations Educational Scientific and Cultural Organization shows Indonesia's ranking in education ranks 64th out of 130 countries in the world. Indonesia's Education Development Index (EDI) is 0.603, below Malaysia 0.71 and Brunei Darussalam 0.672. (UNESCO, December 2017)

The low level of education in Indonesia is indirectly due to the low quality of graduates produced by a tertiary institution in Indonesia, both public and private. A good university will produce good graduates and vice versa. This is as stated in Law No. 12 of 2012 article 51 which reads quality higher education is education that produces graduates who can actively develop their potential and produce knowledge and/or technology that is useful for society, nation and state (Law Law of the Republic of Indonesia, 2012).

To produce reliable students, professional educators and scientists are needed who have: a) broad insight and high concern about education with all its problems, b) deep mastery of the science and technology that becomes its expertise, c) ability to manage and improve the implementation of professional tasks as educational staff, and d) the ability to carry out research and development and technology in the field of education (Uwes, 1999). Lecturers are one of the essential components of an education system in higher education. According to (Hadiantini, Pandia, \& Kaburuan, 2017) in their research results explain that "Lecturer is an educator who has an important role in transforming learners, and the lecturer has to have good qualifications of academic and character." The roles, tasks, and responsibilities of lecturers are very meaningful in realizing the goal of national education, which is to develop the potential of students to become capable, creative, independent human beings and to become and become citizens of a democratic and responsible manner (Law of the Republic of Indonesia, 2003)

A good graduate from a university is inseparable from the role of the lecturer who teaches at the college itself. Good quality lecturers can produce good graduates. This is according to research (Xiao \& Wilkins, 2015) states that "Lecturers who have committed themselves to the students will do high-quality teaching to motivate students to improve their academic achievement and study." Opinion (Mather, 2011) confirms that "All are on the increase across the education sector, and all will eventually impinge upon both performance improvement schemes and government policy." Improvement in the field of education will ultimately have an impact on performance and governance policies. 
The low ability of lecturers in a tertiary institution can be caused by several things, including lecturer awareness and low salaries of lecturers. The results of the study (Assan, 2014) in one of South Africa's higher education shows that "The quality of lecturers is influenced by several factors including lecturer income level, academic qualification and teaching experience, job satisfaction, career achievement." (Moenir, 1992) about the lack of lecturer resources, namely: (1) lack of awareness of staff on the duties and obligations that become their responsibilities, (2) systems, procedures, work autonomy, and inadequate work methods so that the working mechanism does not work as expected, (3) the organization of the ministry that is not synchronized, causing confusing and overlapping,(4) the income of employees is not sufficient to meet the needs of employees and family as a result, do not have a commitment to the organization, (5) the competence staff (lecturers and staff) are inadequate to do the tasks assigned to them, (6) unavailability of adequate service facilities.

Research results (Cruthaka \& Pinngern, 2014) "Lecturers must meet up the demands of stemming from rapid changes in contemporary society and culture to be prepared for future changes." Research results (Khavugwi \& Ogange, 2019) in the Journal of Learning for Development, explained that "The gap is felt by respondents to be a result of inadequate institutional support." It was explained that the occurrence of gaps in increasing the capacity of lecturers occurred due to a lack of support from institutions. McCorkle and Archibald in (Gultom, 2009) stated that various fundamental failures made by the university were in (1) initial consistency and improving quality, (2) caring for funding sources independently but responsibly, (3) maintaining and maintaining staff and resources other deemed potential and contributory, (4) consistency to increase student participation in university performance (students as actors), (5) improve operational efficiency and productivity, (6) reliability for promoting public participation (university committees, employers, and stakeholders other interests), (7) maintaining the power of struggle in uncertainty, (8) consistency in the application of management processes based on university characteristics.

To correct mistakes made by universities that can have an impact on the failure of a college, it is very important to do good management to improve the quality of a college. Management of lecturer resource development is either a business or an approach that can be done. Management of lecturer resource development is a form of management intended to sustain the success of sustainable higher education organizations. Higher education is a sustainable organization. By research conducted by (Peleyu \& Ojebiyi, 2013) states that "There is a relationship of performance with quality management and there is a positive relationship between quality management to the income of an organization."

According to (Paul De Knop, 2010) More of a management philosophy that is considered as a convenient framework used by organizations to ensure systematic and permanent optimization of value-added to maximize the realization of their goals. Management practices are not only intended for industrial and banking organizations. This practice also plays an important role in all organizations. Management practices have a positive impact on customer satisfaction, and management practices are not only needed in developing countries, but even this is very necessary for developed countries (Mercy Ogbari, 2018).

Management in higher education emphasizes learning, teaches according to community needs, and nation-centered research. "Management in higher education emphasizes learning, teaches according to community needs, and nation-centered research" (Srikanthan \& Dalrymple, 2005). Whereas (Avram \& Avram, 2011) in his research stated that Quality management in academic education is pointing the institution of higher education to performance through responsible leadership in achieving goals and adopting strategies that lead to development, encouraging staff to achieve exceptional performance by empowering every employee, orientation of all activities, especially teaching and research activities to meet the needs of high-level stakeholders, continuous improvement of the institutional process, establish a periodic appraisal system to cover the shortfall.

In terms of lecturer quality, the measures used are the latest education diploma, academic qualifications, and teaching experience, research experience, and community service practice. This quality measure is a determining factor for the quality of learning outcomes and educational outcomes in general. Law Number 14 of 2005 requires that lecturers must have functional positions of at least expert assistants (Law of the Republic of Indonesia, 2005). (Supriadi, 2012) said that lecturers are required to have academic qualifications, competencies, teacher certification, physically and mentally healthy and can realize national education goals.

Lecturers as executors of the tri dharma of tertiary institutions are highly expected to be able to shape the character and knowledge of students. The quality of higher education is determined by the quality of lecturer resources in implementing education, research, and community service. Higher education must improve the ability of its lecturer resources to be able to make the higher education institution able to answer the demands of development. 


\section{Theoretical Framework}

Higher education is a place where humans create new knowledge through research, and universities are also institutions dedicated to the dissemination of new knowledge. To achieve that dedication, the academic community has inherent responsibilities, namely education in the form of guiding, teaching and training activities. Furthermore, activities that are research and community service. As for this matter, it is often referred to as tri dharma tertiary education. In the college, both lecturers and students, are required to be more open, free and to learn continuously.

In its implementation, higher education is determined by 2 main factors, namely the leadership and the implementers. From here later it is easy to understand that the increase in higher education resources is centered on developing lecturer resources. The existence of higher education is dedicated to the development of science, so the development of lecturer resources will continue to be needed throughout the development of science and technology

\subsection{Educational and Teaching Tasks}

Education and learning are inseparable from the capacity and readiness of facilities and infrastructure. The quality of learning from research results (Clark LB, 2018) explains that "It seems that the system they work within makes it diff $f$ cult for them to put their critical beliefs about pedagogy into practice in the way they would like. The quality of education will be greatly influenced by governance and the availability of infrastructure. (Fortunato \& Waddell, 1981) detailing the educational and teaching tasks to 9 main activities, namely: (a) Meet all class sections on time; (b) Advise and assist students during regularly scheduled office hours; (c) Update lecture materials regularly; (d) Develop, administer, and score performance focused on learning experience; (e) Provide timely and constructive feedback to student about examination results; (f) Lecture effectively; (g) Facilitate class discussions and self-directed learning; (h) Cover the course materials as outlined in syllabus and catalogs; (i) Effectively us a variety of media and instructional methods for clarity of presentation and to generate and maintain student interest.

In connection with the educational assignment, it can be said that the mastery of the material and technical skills in the teaching-learning process are two absolute things that must be present in the lecturer. Through mastering the material and technical skills of teaching lecturers, teaching that educates can be implemented well. At this point, the implementation of teaching is central because in this activity there is a meeting point between educators and educators in the task of implementing the educational mission.

\subsection{Reseacrh Tasks}

Research that meets the requirements is seen from the research aspects, namely problems with their background, objectives to be achieved, frameworks, premises and hypotheses or research questions, methods, results and research conclusions. Research must be carried out by lecturers. This rapid and complex change and progress of the global economy is determined by the development of science, technology, and art. (Clark BR, 1983) said that as the main institution of modern society from the creation of knowledge, and its dissemination, the academic system accommodates changes in the higher education system that is influenced, among others, by the academic system to change significantly only when pressured by external forces, the system increasingly shows innovation and adaptation between lower units.

Regarding the objectives or research output, lies in the clarity of identification of these objectives. There are many possible forms of output that in principle there are one or more concepts. It may be in the form of conclusions on general trends, generalizations or provisions of existence, essence, and special and general characteristics, the relationship of a behavior process. Methodological consistency is needed, so that there is a common thread that runs straight between paradigms, grids and data instruments, in addition to testing data accuracy and verification.

\subsection{Duties of Dedication to the Community}

Community service is an activity that connects the results of research and mastery of scientific disciplines in the field of education on the one hand, with the improvement of education and the development of research problems on the other hand. However, community service activities in higher education function and are directed also to support development in various walks of life.

Based on these functions and targets, community service benchmarks are not only related to science but also are complex with institutions and society. This means that it involves the issue of administering the activities of citizens outside the campus. According to (Uwes, 1999) aspects of measuring community service are (a) activities on behalf of tertiary institutions; (b) a joint effort between the tertiary institution and the community where the activity is carried out; (c) balanced with educational and research activities; (d) on the initiative of the subject of the implementation of activities; (e) benefit the community where the activity is carried out; (f) support development in one aspect and 
support science development on the other hand; (g) is a scientific practice of the science being studied, so that it is an efficient and effective activity.

\subsection{Duties of Guidance}

Guidance tasks consist of 2 types, namely academic guidance and guidance on writing scientific papers of students. In academic guidance, the characteristic of its integrity lies in the ability to channel the academic potential of students, so that students can follow the academic provisions while still aiming at the aim of study at the tertiary institution. The thesis guidance task/thesis/dissertation is directed to give freedom to the student being guided so that they can express the knowledge they have gained.

\subsection{Administrative Duties}

There are 3 types of tasks in this section, namely structural, committee, and lecturer administration. Structural duties range in position from: (a) Chancellor, Chairperson, Director, (b) Vice-Chancellor, Deputy Chairperson, Deputy Director / Dean, (c) Institutional Head / UPT, (d) Institutional Secretary / Deputy Dean, (e) Head of Center / Head of Department, (f) Head of Center // Head of Department, (g) Head of Lab / Head of Studio / Head of Center, (h) Secretary of University Senate, Institute, High School, Polytechnic, Academy / Secretary of Faculty Senate, and (i) Chair of the Study Program. The next administrative implementation task is the committee position, consisting of ad-hock and permanent. The two positions do not differentiate whether carried out within or outside the college itself. Both must be required with an appointment letter from the leadership of the college.

The last administrative task is lecturer administration. The lecturer administration consists of the task of preparing for teaching and learning through the preparation of Semester Learning Plans (RPS) and Learning Reference Units (SAP), student records and guidance, an archive of scientific / research publications and services, documentation of discussion/seminar activities and other scientific activities. Based on the duties and responsibilities, aspects that must be considered in educational activities, research and community service, that lecturers who have good resources are lecturers who master, follow developments, are able to develop and are responsible for scientific discipline, have the ability to interact with students professionally, respect and protect the rights of students, set an example in attitudes and thoughts, be able to develop a curriculum that is relevant, effective and efficient.

\section{Methodology}

This study uses a qualitative approach with a case study method in which the data collected is in the form of words, pictures and not numbers, the research report will contain data excerpts to give an overview of the lecturer recruitment at STKIP BBG Banda Aceh. The place of this research was at and time of research at the STKIP BBG Banda Aceh, starting from January to May 2019 regarding the recruitment of lecturers at the STKIP BBG Banda Aceh. The research subjects consisted of the chairperson, assistant chairperson, quality assurance agency, research and community service institutions, chair of the study program, and lecturers at the STKIP BBG Banda Aceh. To determine the validity (trustworthiness) of the data required inspection techniques. Four criteria can be used to test the validity of data, namely the degree of trust (credibility), transferability, dependability and the certainty of data and research results. Besides that, triangulation is also carried out. Triangulation is a cross-examination of various sources used. Triangulation that is widely used is triangulation with sources that are comparing and checking back the degree of trust in information obtained through different time and tools in research.

Triangulation is more clearly done by way of 1). Comparing interview data with observations, 2). comparing what people say in public with what is said in private, 3). compare what people say about the research situation with what is said all the time, 4). comparing one's circumstances and perspectives with various views of people from various backgrounds, 5). compare the results of the interview with the contents of the relevant documents. Triangulation is carried out in conjunction with field observations so that researchers can record complete data. Thus, the data from the results of this study deserve to be utilized. According to (Muhadjir 2013) qualitative research data analysis techniques in data collection using techniques; editing, category, displaying data and interpretation.

\subsection{Participant Sample}

The subject that is the source of the data in this study is called the informant. To determine the informants in this study with certain considerations. "The selected information functions to get the maximum information, not to be generalized." (Lincoln \& Guba, 1985). The power of people as data sources is that at least it must be investigated in depth giving a lot of understanding about the topic (Moleong, Qualitative research methodology, 1999). In this study, the selection of informants was carried out using a purposive sampling technique. This technique is used to select and select informants who truly master information and issues in-depth and can be trusted to be a reliable source of data. Using this purposive technique, researchers can determine to sample by the objectives of the study. The sampling 
referred to here is not representative of the population, but is based on the relevance and depth of information, however, it is not only based on the researcher's subjective but based on themes that appear in the field.

As it is known that the informant is the source of the data also taken by the quality and characteristics. The researcher tries to do a study and assessment to determine the informant to be tracked, traced, studied and verified and then determined as a research participant. As revealed earlier, the determination of informants as research targets was carried out by the quality and characteristics of the informants. In the process of collecting data, this research involved foundations, chairpersons, vice-chairpersons, quality assurance agencies, research institutes, and community services, study programs and lecturers. As for those who will be involved in this research as in the following table.

Tabel 1. Research Informan Data

\begin{tabular}{cc}
\hline No & Name \\
\hline $\mathbf{1}$ & Dr. Lili Kasmini, M.Si \\
$\mathbf{2}$ & Rita Novita, M.Pd \\
$\mathbf{3}$ & Fitriati, M.Ed \\
$\mathbf{4}$ & Intan Kemala Sari, M.Pd \\
$\mathbf{5}$ & Sri Wahyuni, M.Pd \\
$\mathbf{6}$ & Zaki Al-Fuad, M.Pd \\
$\mathbf{7}$ & Lina Amelia, M.Pd \\
$\mathbf{8}$ & Rika Kustina, M.Pd \\
$\mathbf{9}$ & Ahmad Nasriadi, M.Pd \\
$\mathbf{1 0}$ & Zikrur Rahmat, M.Pd \\
$\mathbf{1 1}$ & Ully Muzakkir \\
$\mathbf{1 2}$ & Aprian Suhabnanto, M.Pd \\
$\mathbf{1 3}$ & Teuku Mahmud, M.Pd \\
$\mathbf{1 4}$ & Drs. Musdiani, M.Pd \\
$\mathbf{1 5}$ & Hijatul Qomariah, M.Pd, M.TESOL \\
$\mathbf{1 6}$ & Rismawati, M.Pd \\
$\mathbf{1 7}$ & Didi Yudha Pranata, M.Pd
\end{tabular}

The total number of research people in the above table is 17 people. All participants can be predicted to be objective data and it is expected that the discovery of data by the objectives of this study. Especially when researchers explore the management of lecturer resource development, then, of course, this becomes very important to happen developments in his research.

\subsection{Data Collection Techniques}

To obtain data, the researchers traced data to the STKIP BBG Banda Aceh to conduct interviews with foundations, chairpersons, deputy chairs, quality assurance agencies, research and community service institutions, study programs and lecturers. In addition to adding to the objective treasures, the researchers also conducted observations and observations through visits to classes, lab rooms, libraries, lecturers' rooms, study programs, leaders, sports fields and the campus environment at large. The researcher also traced written documentation data adjusted to the facts and data found through observation interviews.

The success of quality research is highly dependent on the accuracy and completeness of the field notes prepared by the researcher. Therefore, the data collection techniques used in this research are observation, interview and documentation study. Data collection techniques can be seen in the following figure. 


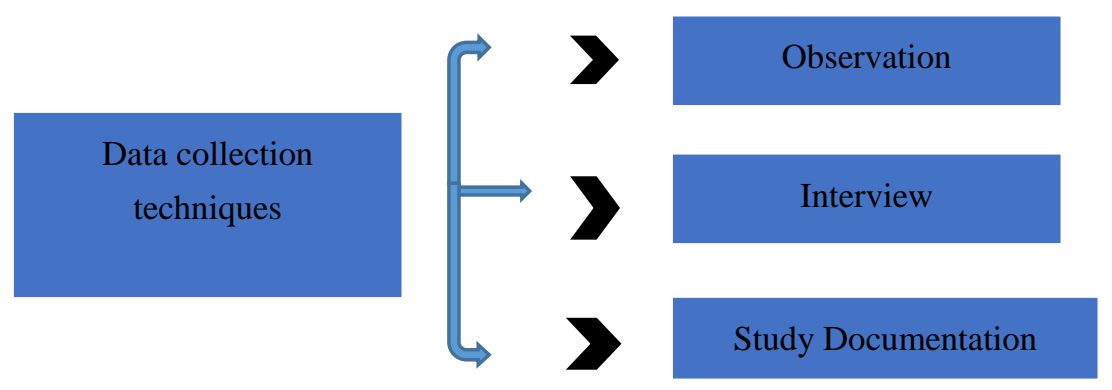

Figure 1. Data Collection techniques

\section{Result}

\subsection{Pendididkan}

The results of the interview on the implementation of the tri dharma in the field of education were, that at the beginning there were still lecturers who had an S1. As one form of management of lecturer resource development, STKIP BBG Banda Aceh, sent them to the Masters level again with a foundation scholarship. If there are lecturers who do not meet the target, they will be returned to administrative staff. This is as expressed by Musdiani who said that:

When I was a bachelor, the campus gave me facilities in the form of college permits on Friday, facilities in the form of tuition fees even though on Monday-Thursday I continued to work.

This is also in line with what was expressed by Lili Kasmini who said that:

In the beginning there was, so to increase the resources of the lecturers here, the university management sent them to attend S2 education, there were about 4 people we sent back to school. If we don't want it and we can't return it to administrative staff. There is 1 person who can't because of family reasons.

From the above statement we can see the seriousness of the Banda Aceh STKIP BBG in the process of developing lecturer resources. This can be seen from their seriousness at the beginning by sending them to school. At present all lecturers in the STKIP BBG Banda Aceh are educated S2. This is done at the beginning of the recruitment. It is hoped that the development of lecturer resources will be easier. This is as revealed by Lili Kasmini's statement that said: "If for S2, all of our lecturers here are all Masters. This was also expressed by Fitriati who said that: "For the level of education, the quality of management has done a good development, where all lecturers have S2. This information was also obtained from Ully Muzakir who said that: "Our reference to the applicable regulations. Lecturers must be linear, S2 so that has been our reference so far. "

In developing lecturer resources, STKIP BBG Banda Aceh has also sent lecturers to continue their doctorate at various universities in Indonesia. Of the 12 people who were sent to complete their S3 education, 4 of them had already completed and returned to campus. This was revealed from information provided by Ahmad Nasriadi who said that: "Of the 12 lecturers sent completing their S3 education, only 4 completed." This was also revealed by Lina Amelia who said that: "For the $\mathrm{S} 3$ only 4 people returned from his education. "

For courses taught by lecturers, STKIP BBG Banda Aceh has also adjusted to the field of science and expertise. This is as expressed by Sri Wahyuni:

If in English Education Study Program, overall lecturers in study programs are in accordance with the subjects taught. For general courses, lecturers who will teach general courses from other study programs will be taught, such as Indonesian, religion, Pancasila and entrepreneurship courses.

The same thing was expressed by Hijjahtul Qomariah who stated that:

During my study program, I taught courses according to my education. Sometimes I also teach English courses in other study programs. But still in accordance with my education.

This statement was also expressed by Didi Yudha Prabudi who stated that:

The campus adjusts the lecturer education with the courses that will be taught. This was done from the beginning of reception when I entered here.

From the results of the study it was revealed that from the process of implementing the tri dharma of higher education in the field of education it was found that initially lecturers at the STKIP BBG Banda Aceh still had S1 education. In terms of developing lecturer resources, STKIP BBG Banda Aceh sent them to further study S2. At present, all lecturers 
at the STKIP BBG Banda Aceh already have S2 degrees. Besides that, STKIP BBG Banda Aceh sent lecturers to continue their education at the doctoral level. The process of sending lecturers is done in rotation based on length of work, and functional positions. This is an obstacle in the process of developing lecturer resources in the field of education. From the results of the study it was found that this process began to produce results, where the STKIP BBG Banda Aceh already had 4 lecturers completing their S3 education.

\subsection{Teaching}

STKIP BBG Banda Aceh has changed the curriculum into a curriculum based on KKNI (Indonesian National Qualification Framework). The curriculum includes a curriculum related to the world of work so that graduates can later be absorbed by the world of work in addition to being a professional teacher. Changes to the curriculum also require the Banda Aceh BBG STKIP to increasingly improve the development of lecturer resources they have. This is in line with what was said by Rita Novita that:

We have a syllabus, curriculum set. In 2016 we have made changes to the curriculum, we use KPT. Curriculum references to the KPT earlier. Curriculum guide up to study program level. Where there are references, details of the course. In our institution, we have a curriculum guide. In institutions it is general. Subjects in study programs, coding systems, credit systems, their assessment. Everything is placed in the guide.

The same thing was expressed by Lili Kasmini who stated that: "Currently the reference is KKNI in its application." Rita Novita also said that:

KPT is indeed the main focus. So he pays attention to the qualifications framework nationally (KKNI) in addition to knowledge, also very concerned about the world of work. In all study programs, we have so that students besides educators can be anything. For example, there is mathematics education, there is uplander mathematics, then there is a research assistant, that is what we break into several learning references in the curriculum.

Lili Kasmini also said:

By using this KPT we can make the absorption of higher education graduates absorb more into other fields which not only have to become teachers. For example students of English language study programs, where in addition to being a teacher they are also equipped with the knowledge of how to become a guide in the world of tourism. We equip it in the curriculum.

Another informant from Zikrur Rahmat also said that:

Thank God we are by the study program's vision. Professional, entrepreneurial and sporting. This professional because we are in the teacher we are professional in the teacher, entrepreneurial spirit we also educate students on how to become a coach, opening a sports shop business.

In learning activities, lecturers have made RPS at the beginning of learning to be input in the opensimka system owned by Banda Aceh STKIP BBG. From here it can later be seen how far the lecturer resources are capable of conducting the teaching process to students. This is by what was stated by Rita Novita that:

$100 \%$ can be sure the lecturer has and prepares an RPS. Because indeed the system that we have lecturers must have an RPS at the beginning. Lecturers must upload RPS. Because if the lecturer does not upload the RPS, then they cannot access to the next stage, whether grades, student absences and so on.

Mahmud also said that: "In the new semester, the lecturer prepares the RPS with the KPT demands for the taught subjects." The same thing was expressed by Hijjahtul Qomariah who stated that:

Create an RPS for each course that is taught and uploaded in the opensimka system to be able to continue entering and find out the number of students, classrooms, and others.

To monitor the development of lecturer resources in the teaching field, the STKIP BBG Banda Aceh evaluates each semester. This was revealed from Ully Muzkir's statement which said that:

The campus conducts monitoring at the beginning and in the middle of the semester. This activity is to see the suitability of the curriculum conducted by lecturers. This evaluation will also see which lecturers should be improved and given the training to improve their resources.

Fitriati also said that:

Evaluation is done every semester as much as 1 time. Evaluation is carried out jointly between BJM and UPMP Study Program to see how the lecturer resources in the teaching field.

Also, Lina Amelia said that: "A lecturer evaluation is carried out twice a year by BJM and UPMP in the study program." 
There is. We will later work with the Quality Assurance Agency (BJM) to conduct an evaluation. In the middle of the semester, they will enter the room to check on the teaching lecturer, the accuracy of the RPS with the lecturer teaching time. This activity is carried out mid and end of the semester.

Regarding this matter, Aprian Subhananto also stated: "There will be monitoring and evaluation conducted later by BJM and study programs every semester to observe the suitability of RPS, teaching materials and teaching abilities of lecturers." Rismawati also said that:

Study Program and BJM conduct monitoring and evaluation of lecturers by looking at several provisions. Are RPS and teaching materials appropriate, teaching ability, discipline and so on.

Based on the results of the study it was found that lecturers at the STKIP BBG Banda Aceh must have made an RPS before teaching. For the development of lecturer resources, the STKIP BBG Banda Aceh provides training to lecturers on how to prepare RPS and learning methods. STKIP BBG Banda Aceh also conducts evaluation and monitoring every semester. Later, STKIP BBG Banda Aceh can find out the ability of lecturers in teaching. The results of the evaluation and monitoring carried out to be used as a basis in the process of developing lecturer resources.

\subsection{Research and Dedication to the Community}

Based on the results of interviews in the section of research and community service, it can be found that what is used as a reference in research and community service is a manual issued by the Institute of Research and Community Service (LPPM) STKIP BBG Banda Aceh. This was revealed from Intan Kemala Sari's statement which stated that:

Reference is in the form of guidelines for research and service that apply internally. Only the difference will be different outcomes with Dikti. And later it will be applied to BKD inside.

The same was expressed by Lili Kasmni also revealed that: "We are referring to the research and devotion guidelines issued by LPPM." LPPM. "The same opinion was also expressed by Ully Muzakir who said that:" Reference in this activity guideline issued by LPPM. " In the last 3 years (2016-2018), the development of lecturer resources in conducting research was very high. This can be seen from the increase in research conducted by lecturers. Data collected, $100 \%$ of lecturers conduct research and around $70 \%$ of lecturers win research grant funds conducted by the Ministry of Research, Technology, and Technology. This was revealed from the IKS statement which stated that: The one who followed all the lecturers proposed research, but those who won were around $70 \%$ of the total.

This is by what was expressed by Lili Kasmini who stated that:

We see that $100 \%$ received research grant funds. if we look at the title a little. But one title can be 2-3 lecturers. This means that all lecturers have obtained and conducted research.

Other information was also obtained from Rita Novita who said that:

From the explanation from LPPM, there was always an increase from and grants, both in terms of quantity and increase. We used to only play in novice lecturers or competing grants. Now someone is entering into law, applied research. In terms of increasing, in terms of skim also increased.

Also, Fitriati added that: "It seems that in the last 3 years, all lecturers have conducted research. Because in 1 research activity a team is usually done between 2-3 lecturers. " From the interview findings, we can see that the development of lecturer resources in research activities was carried out very well. This is evident from the increase in research activities carried out by lecturers. In contrast to research, there are only a few lecturers who have won grants from Kemristekdikti. This was revealed by Intan Kemala Sari who said that: If for the dedication it was slightly reduced, out of 24 proposals only 2 won. But the proposal continues to increase. Another thing was revealed from Lina Amelia's statement which stated that: Dedication is carried out only at the level of service that is done independently. There is no dedication to the level of Ristekdikti to get grant funds.

The same thing was expressed by Rita Novita who stated that: Just as research in our service has increased. Finally, in recent years there has been an export product, PKM.

The process of developing lecturer resources in the service activities focuses more on the reporting of the Lecturer Workload (BKD) which requires lecturers to conduct service activities once a semester. This is as expressed by Rika Kustina that: "Because this dedication is done for BKD lecturers." Even to motivate the development of this lecturer resource, STKIP BBG Banda Aceh provides in the form of incentives to lecturers who successfully publish their research results in international journals that of high reputation. This is by what was expressed by Intan Kemala Sari who said that:

After the seminar later, the lecturer will publish the results of research and dedication to national and international journals. There is compensation or incentives given by the campus if it can be published in high-reputed international 
journals.

This is also in line with what was stated by Ully Muzakir that:

At present, the foundation has planned to provide compensation for lecturers who publish their research results to high-reputed international journals.

From the results of this study, it was revealed that 70\% of lecturers at the STKIP BBG Banda Aceh had won research grant funds. This process is the result of training and incentives given to lecturers. The obstacle for lecturers is still on the publication of research results in high-reputed international journals. To overcome this problem, incentives are given to lecturers to continue to increase the resources they have. This is all the process of developing lecturer resources carried out at the STKIP BBG Banda Aceh.

\section{Result}

\subsection{Education}

Currently, lecturers at the STKIP BBG Banda Aceh have a master's education (S2). Initially, there were still lecturers with a bachelor's degree. However, the STKIP BBG Banda Aceh has conducted coaching to develop lecturer resources by sending them back to $\mathrm{S} 2$ on-campus scholarships. This can be seen from the seriousness of Banda Aceh's STKIP BBG in developing their lecturer resources. This is consistent with Lili Kasmini's statement that:

In the beginning, there was, so to increase the resources of the lecturers here, the university management sent them to attend S2 education, there were about 4 people we sent back to school. If we don't want it and we can't return it to administrative staff.

By allowing lecturers to continue their studies, they will add lecturer pedagogical competence. This indicates that the campus has succeeded in developing lecturer resources. This is by research (Horokhivska, 2018) revealed that:

Give great attention to the quality of lecturers such as the ability to independently complete complex tasks, acquire new knowledge and skills, have a positive outlook about one's personality, communicate with benefits with students and colleagues.

In line with that (Demirel, Teykur, Celik, Safali, \& Rich, 2018) revealed in his research that "The ability of lecturers must be increased by supporting them to continue their studies." In this education process, the STKIP BBG Banda Aceh sent lecturers to attend further education at the doctoral level. The delivery system in turn. This is done to maintain the composition of lecturers who teach on campus. Of the 12 sent since 2012, only 4 people have finished and returned.

\subsection{Teaching}

STKIP BBG Banda Aceh already uses a curriculum based on KKNI (Indonesian National Qualification Framework). By using this curriculum, STKIP BBG Banda Aceh has included courses that can absorb graduates in the world of work in addition to teacher training that is the focus. (Abukari \& Ahmed, 2019) in their research revealed that:

Higher education seeks to enhance the wellbeing of multiple ecologies including the promotion of learning that informs students' practice at the workplace, developing critical thinking and reflective practice to help deal with multiple issues in society.

This was also expressed by (Ishomuddin, 2015) in his research that the The national education curriculum designed by the government to products graduates relevant to the world of work has been initiated by the government to respond to today's global world. The curriculum is given the name of the Indonesian National Qualifications Framework. In 2017 all the universities must make changes and implement curriculum based on KKNI. To enhance the development of lecturer resources, the STKIP BBG Banda Aceh complements existing facilities and infrastructures as a scientific development. In the learning process in STKIP BBG Banda Aceh also has used ICT (Information, Communication, Technology) so that it can make it easier in the learning process. Of course, this process requires lecturers to be more skilled and hone their resources. This was revealed in a study (Ghavifekr, Razak, Muhammad Faisal A. Ghani, Meixi, \& Tengyue, 2014) that "With ICT integration in the classroom, students will be able to engage in interactive tasks with a wider range of information and knowledge during their learning. "Meanwhile (Hatlevik \& Arnesth, 2012)" At the same time, the teachers' beliefs and attitudes will influence them to integrate ICT in their teaching practice. "

Early in the lecturer learning, incorporating RPS (Semester Learning Plan) into the system so that it can be uploaded by students who take the course. The tremendous potential of ICT in promoting the learning outcomes with more recent knowledge without obstruction on accessibility and distance limitation (Ghavifekr, Razak, Muhammad Faisal A. Ghani, Meixi, \& Tengyue, 2014). To find out whether the development of lecturer resources in the teaching field has been successful, the Banda Aceh STKIP BBG has conducted an evaluation every semester. This evaluation is to 
determine the understanding of lecturers in making RPS, synchronization between RPS with teaching materials, how to teach and discipline. Evaluation of lecturers was carried out to find out the results of the process of developing resource lecturers in universities (Toytari, Tynjala, Piirainen, \& Ilves, 2017). The evaluation is carried out by BJM (Quality Assurance Agency) and UPMP (Study Program Quality Assurance Unit). The results of this evaluation will make it easier for the management of STKIP BBG Banda Aceh to provide training and education for lecturers so that the development of lecturer resources can be successful.

\subsection{Research and Dedication to the Community}

The research and community service program at STKIP BBG Banda Aceh has run well. This can be seen by the existence of a guidebook for research and community service issued by the LPPM (Institute for Community Service Research) STKIP BBG Banda Aceh. In addition to education and teaching, research and community service are things that should not be missed in the process of developing lecturer resources. (Suhaemi \& Aedi, 2015) Revealed in his research that Lecturers are professional educators and scientists whose main job is to transform, develop, and disseminate knowledge, technology, and art through education, research and community services.

The success in developing lecturer resources in this field is evident from the fact that over the past 3 years (2017-2019) there were 70\% of lecturers at the Banda Aceh STGIP BBG who won lecturer research grants. The development of lecturer resources in the field of research and community service is also given various training to lecturers. The training is expected to be able to increase the resources of lecturers in the field of research and community service.

Research and community service is very important. Considering the importance of this activity, the Banda Aceh STGIP BBG is developing lecturer resources in the field of research on an ongoing basis. The development of lecturer resources in the field of research must also be accompanied by funding for research activities and community service carried out by lecturers. In accordance with what was expressed by (Dulmus \& Cristalli, 2012) that: "Enhance research capacity if they are effectively equipped with knowledge, skills, and funding to integrate research and development into ongoing organizational activities."

Due to the importance of developing lecturer resources in the field of research and dedication, the STKIP BBG Banda provides incentives for lecturers who have successfully published their research results and services to high-reputed international journals. All this was done so that the development of lecturer resources would be better.

\section{Conclution}

Lecturers at STKIP BBG Banda Aceh already have master's degrees. STKIP BBG Banda Aceh sent lecturers to continue their S3 education in turn, where of the 12 people sent, 4 had returned to complete their S3 education. This is done by the campus management in the resource development hall lecturer.

The management of STKIP BBG Banda Aceh has carried out and changed into the KKNI-based higher education curriculum. Include courses related to the world of work so that graduates can be absorbed by the world of work other than becoming a professional teacher. The curriculum has also been entered into entrepreneurship to become an entrepreneur. Lecturers prepare RPS at the beginning of the semester where there will be an evaluation and monitoring of 1 semester each to see the suitability of the RPS, teaching materials and the ability of the lecturer to teach. Evaluation and monitoring are carried out by BJM together with UPMP in the study program.

The research program has been running well, where there are a research and service manual issued by LPPM. In these 3 years, all lecturers have conducted research and service activities. For grants, $70 \%$ have received research grants, but only 2 proposals have been funded for service by the Department of Education for 3 years. Lecturers work together in research and service activities carried out. In addition, lecturers also involve students in their research and service activities. Management STKIP BBG Banda Aceh conducts training and guidance for doesn't. to be able to carry out research and service activities, so that they can develop the lecturer resources. Lecturers give reports on the results of their research and service to LPPM in hard copy. Lecturers also publish the results of their research and service in international journals. To develop lecturer resources, the campus provides incentives for lecturers who have successfully published research articles and devoted to high-reputed international journals.

\section{Refernces}

Assan, T. B. (2014). Perceptions of lecturers on quality assurance in higher eduction teaching and learning process. Int J Edu Sci, 339-347. https://doi.org/10.1080/09751122.2014.11890196

Avram, E. M. \& Avram, R. M. (2011). Quality Management in Higher Education Institution. Holistic Marketing Managemet, 41-47.

Clark, B. R. (1983). The Higher Education System, Academic Organization in Cross-National Perspective. 
California: University of California Press.

Clark, L. B. (2018). Critical pedagogy in the university: Can a lecture be critical pedagogy? Policy Futures in Education, 1-13. https://doi.org/10.1177/1478210318787053

Cruthaka, C. \& Pinngern, O. (2014). Development of a training program for enhancement of technology competencies of university lecturers. Acadmic Journal, 57. https://doi.org/5897/IJEAPS2016.0465

Fortunato, R. T. \& Waddell, D. G. (1981). Personnel Administration in Higher Education: Handbook of Faculty and Staff Personnel Practices. California: Jossey Basic Inc.

Gultom, S. (2009). Keberlanjutan Program Studi: Kajian Pengaruh Kepemimpinan, Atmosfir Akademik, Manajemen Internal dan Produktivitas Terhadap Keberlanjutan Program Studi di Universitas Negeri Medan. Jakarta: Disertasi, Program Pascasarjana Universitas Negeri Jakarta.

Hadiantini, R., Pandia, S. P. \& Kaburuan, E. R. (2017). Lecturer Performance Factors in Private Universities in Bandung City. International Journal of Human Resource Studies, 231-239. https://doi.org/10.5296/ijhrs.v7i4.12079

Khavugwi, B. \& Ogange, B. O. (2019). The effects of institutional support factors on lecturer adoption of elearning at conventional university. Journal of Learning for Development, 6(1), 64-75. Retrieved from https://j14d.org/index.php/ej14d/article/view/326

Lincoln, Y. S. \& Guba, E. G. (1985). Naturalistic Inquiry. California: Sage Publication. https://doi.org/10.1016/0147-1767(85)90062-8

Mather, K. (2011). Teacher, lecturer or labourer? Performance management issues in education. Management in Education, 26-31. https://doi.org/10.1177/0892020610388060

Mercy Ogbari, B. T. (2018). Stratgeic Impreatives of Total Quality Management and Customer Satisfaction in Organizational Sustainability. International Journal of Academic Research in Bussiness and Social Sciense, 1-22.

Moenir, H. (1992). Manajemen Pelayanan Umum di Indonesia. Jakarta: Bumi Aksara.

Moleong, L. J. (1999). Metodologi penelitian kualitatif. Bandung: PT. Remaja Rosdakarya.

Paul De Knop, J. V. (2010). Quality Management in Sports Clubs. Sport Management Review, 57-77. https://doi.org/10.1016/S1441-3523(04)70045-5

Peleyu, J. O. \& Ojebiyi, O. A. (2013). Lecturers' Performance Appraisal and Total Quality MAnagement of Public Universities in South-Western Nigeria. British Journal of Education, 41-47.

Peraturan Pemerintah. (1999). Peraturan Pemerintah No 60 tentang Pendidikan Tinggi Tahun 1999 pasal 6.

Robbins, S. P. (2008). Perilaku Organisasi, Buku I: Organizational Behavior, terjemahan Hadyana Pujaatmaka. Jakarta: Salemba Empat.

Srikanthan, G. \& Dalrymple, J. (2005). Implementation of a Holistic Model for Quality in Higher Education. Quality in Higher Education, 69-81.https://doi.org/10.1080/13538320500077686

Supriadi, O. (2012). Profesi Kependidikan. Yogyakarta: LaksBang Presindo.

Undang-Undang Republik Indonesia . (2012). Undang-Undang Republik Indonesia Nomor 12 Tahun 2012 Tentang Pendidikan TInggi Pasal 51 ayat 1.

Undang-Undang Republik Indonesia. (2003). Undang-Undang Nomor 20 Tahun 2003 Tentang Sistem Pendidikan Nasional, Pasal 3, ayat 1. Jakarta.

Undang-Undang Republik Indonesia. (2005). Undang-Undang Nomor 14 Thun 2005 Tentang Guru dan Dosen pasal 47 ayat $b$.

UNESCO. (Desember 2017). Peringkat Pendidikan 130 Negara di Dunia. Badan Perserikatan Bangsa-Bangsa.

Uwes, S. (1999). Manajemen Pengembangan Mutu Dosen. Ciputat: PT. Gramedia Pustaka Utama.

Uwes, S. (1999). Manajemen Pengembangan Mutu Dosen. Jakarta: PT. Logos Wacana Ilmu Utama.

Xiao, J. \& Wilkins, S. (2015). The effects of lecturer commitment on student perceptions of teaching quality and student satisfaction in Chinese higher education. Journal of Higher Eduction Policy and Management, 98-110.https://doi.org/10.1080/1360080X.2014.992092 